\section{Virtual elimination of iodine deficiency disorders in Bolivia ${ }^{1}$}

1 Condensed version of the report of an external evaluation team of the Bolivia IDD Control Program, titled "Virtual elimination of iodine disorders achieved in Bolivia." La Paz: PAHO/WHO, UNICEF, ICCIDD, PAMM; 2 September 1996.

\section{INTRODUCTION}

Bolivia has long been known to have a severe national problem with iodine deficiency, characterized by the ubiquitous and obvious signs of goiter and cretinism. Large-scale surveys of children in primary schools, conducted in 1981 and 1983, found a national goiter prevalence of over $60 \%$ and demonstrated that the entire country was affected by iodine deficiency to a similar degree.

In 1983 the Government of Bolivia established the National Program for the Fight Against Goiter (PRONALCOBO), led and overseen by the Ministry of Social Services and Public Health. Establishment of the Program was assisted by funds from the Government of Italy provided through the WHO/ UNICEF Joint Nutrition Support Program. Since 1991 the Program has benefited from continued technical and financial support from the UNICEF Subregional Andean Iodine Deficiency Disorders Control Program, and since 1994 it has also been supported by funds made available to UNICEF by Kiwanis International.

Drawing on prior experience from salt iodization projects in Tarija and Potosí departments, the Program adopted the iodization of all salt for human consumption as the main longterm strategy. In addition, iodized oil was made available up to 1994 in areas of known high endemicity. The major strategy, presently known as Universal Salt Iodization, is being implemented by the small-scale salt processing enterprises in the country, which have recently organized themselves into the Association of Salt Processors of Bolivia. The Program has taken full advantage of the long Bolivian cultural tradition of communitybased participation.

Information, education, and communication activities have been crucial in generating political and public awareness. At the beginning of the Program, strategic alliances were made with the People's Health Committees to mobilize the population during large-scale iodized oil supplementation campaigns. Health personnel at all levels have received continuous training about the importance of consuming iodized salt. Since 1992, information, education, and communication activities have focused on areas with low iodized salt availability, and major emphasis has been given to the use of 
alternative interpersonal communication techniques, such as street theater and mural painting. All activities were supported by frequent transmission of radio messages throughout the country in local languages.

Data from the Program's surveillance component demonstrate that Bolivia has made continuous progress in reducing the national problem of iodine deficiency disorders (IDD) since 1983. On the basis of encouraging information obtained through routine monitoring of iodized salt production, as well as corroborating data on salt availability in households and urinary iodine excretion patterns in the population, in August 1996 the Government of Bolivia invited a group of experts from PAHO, UNICEF, the International Council for Control of Iodine Deficiency Disorders (ICCIDD), and the Program against Micronutrient Malnutrition (PAMM) to review, with the national program staff, the progress made toward the national elimination of IDD. The review team was requested to determine whether Bolivia had met the criteria for the virtual elimination of IDD established by international groups and to suggest ways in which the Program could be improved to increase its effectiveness and the likelihood of its sustainability.

The Bolivia Program has focused its recent efforts on gathering reliable data on the population's iodized salt use and urinary iodine excretion levels, indicators for which WHO, UNICEF, and ICCIDD had recommended criteria in 1992 for measuring progress toward eliminating IDD as a public health problem (1). Two other indicators-thyroid size and concentration of thyroid stimulating hormone (TSH)-were also suggested as being useful, but the review team supported the Program's decision to concentrate on the other two. Therefore, the criteria used by the team in evaluating Bolivia's achievement were the following: (1) over $90 \%$ of households should be consuming effectively iodized salt, and (2) less than $50 \%$ of the population should have urinary iodine excretion levels below $100 \mu \mathrm{g} / \mathrm{L}$, with less than $20 \%$ below $50 \mu \mathrm{g} / \mathrm{L}$.

The ICCIDD has also proposed guidelines for assessing progress toward IDD elimination (2), namely, that IDD could be considered eliminated as a public health problem if the criteria suggested in 1992 for any two of the four indicators were met.

The review team analyzed surveillance data on indicators of iodine deficiency and use of iodized salt, as well as methods of salt iodization and salt quality assurance systems. The team's findings, conclusions, and recommendations are summarized below.

\section{INDICATORS OF IODINE DEFICIENCY AND USE OF IODIZED SALT}

The Program has made continuous efforts to track progress in increasing iodized salt production and availability and in reducing the prevalence of IDD. The surveillance process has provided the data and analysis needed to guide program development.

\section{Availability and use of iodized salt}

Data on the availability of iodized salt in communities was collected in a series of surveys carried out between 1991 and 1995. Based on data collected in 1991, a system was devised to identify departments where the limited use of iodized salt indicated the likelihood of continued risk of IDD. A follow-up survey was performed at the end of 1993 in communities found in 1991 to be at high risk. It showed that the availability of iodized salt in the sample households had increased from less than $20 \%$ in 1991 to $44 \%$ in 1993. Salt use surveys in highrisk communities continued between 1993 and 1995, along with guidance on promotional and marketing activities to increase the use of iodized salt in these areas.

In 1994, data on the consumption of iodized salt was collected as part of the Bolivia Demographic and Health Survey (3). The survey covered 9114 households throughout the country and found that, overall, $81 \%$ used iodized salt; however, there was a large disparity between the prevalence of use in urban areas (91\%) and rural areas (64\%).

Use of iodized salt was also estimated in the Multiple Indicator Cluster Survey (4) conducted in 1996. All households in the survey were asked to provide a sample of the salt used in the preparation or consumption of the previous day's main meal. For the country as a whole, $93.4 \%$ of the samples consisted of fine, iodized salt packed in bags carrying the Program's logo. However, in rural areas $5.3 \%$ of the households used block or granular salt, and only $10 \%$ of the samples of those types of salt were found to be iodized. Consumption of granular and block salt has decreased from $23 \%$ of the country's total rural population in 1994 to $5 \%$ in 1996, but data indicate that it may still be relatively high in some Andean and altiplano departments.

\section{Data on urinary iodine excretion}

The amount of iodine excreted in the urine is regarded as one of the most reliable indicators of the adequacy of iodine intake. However, this indi- 
cator was not used in Bolivia until 1987, and thus there is no baseline information on urinary iodine excretion before the salt iodization intervention started. It is also not possible to analyze trends in urinary iodine excretion as the use of iodized salt increased, because data on this indicator has been gathered to monitor a variety of interventions among different population groups.

In June 1996, information on urinary iodine excretion, as well as use of iodized salt (see above), was collected as part of the national Multiple Indicator Cluster Survey (4). The median urinary iodine excretion for Bolivia as a whole was found to be $250 \mu \mathrm{g} / \mathrm{L}$, and only $10.2 \%$ of all urine samples had a concentration below $50 \mu \mathrm{g} / \mathrm{L}$, the level below which a community is considered to be at moderate to high risk of suffering IDD.

Disaggregation of the data to the department level showed that mean urinary iodine excretion was above the minimum level in all departments. However, in reviewing the analysis, the team suspected that in some departments the high levels found in urban and periurban clusters may have masked low levels in rural clusters. At the team's request, the urinary iodine data were further disaggregated to the provincial (cluster) level and plotted on a map. The map showed distinct clusters with low median urinary iodine levels, which were located contiguously in the neighboring Andean departments of Chuquisaca, Potosí, and Tarija. The team was informed that the affected provinces in these departments were relatively poor. Although the number of samples of urine collected in each province was far too small to ensure the statistical validity of estimates for individual provinces, the clustering found in neighboring areas was thought to be very unlikely to occur by chance. Thus, there is some indication that a number of rural areas in some provinces may still have inadequate iodine intake. The distribution of urinary iodine values, shown in Figure 1, also suggests that there may be distinct population groups which have a lower iodine intake than the country as a whole.

\section{Goiter prevalence}

The team reviewed the available information on goiter prevalence, which shows that the high prevalence of endemic goiter $(65 \%)$ at the start of the Program decreased to $21 \%$ in 1989 and $4.5 \%$ in 1994 , most probably as a result of the interventions. However, it was recognized that the palpation method of diagnosing goiter is not precise; therefore, the assessment of thyroid size had been easier and more reliable at the beginning of the period, when there was a higher prevalence of large goi-
FIGURE 1. Distribution of urinary iodine concentration, Bolivia, 1996

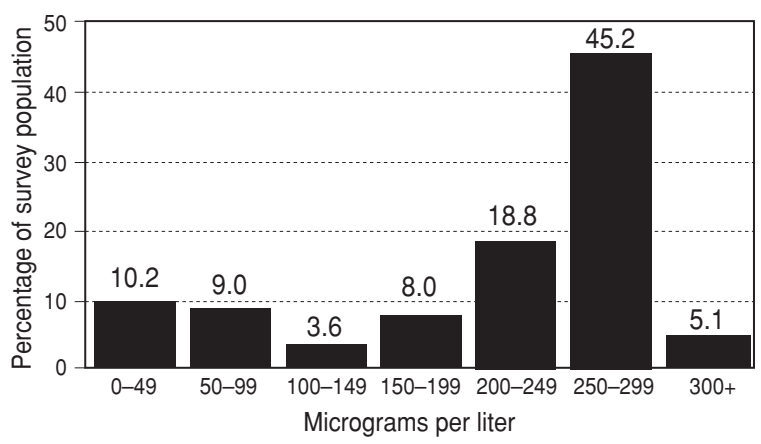

ters. Despite the lack of precision of the method, the team concluded that there was a definite decrease in the prevalence of goiter, which was consistent with the parallel increase in the consumption of iodized salt and the present adequate levels of urinary iodine excretion.

\section{Laboratory capacity}

The review team regarded the National Laboratory for Iodine as an important national asset. Procedures for determining urinary iodine excretion were examined in detail and found to be satisfactory. However, the team was concerned that methods for determination of the iodine content of salt differed between the La Paz laboratory, which used a spectrophotometric method, and the five regional laboratories, which used titration.

\section{SALT IODIZATION AND QUALITY ASSURANCE}

Virtually all salt consumed in Bolivia is produced in the country. In 1990 the estimated total salt production in Bolivia was about 70000 metric tons, of which 20000 was iodized. By the end of 1995, about 53500 metric tons of the same total amount was iodized-an impressive increase in iodized salt production.

At present, 52 salt processing enterprises in the country-mostly small family businesses-are producing iodized salt. They have been visited regularly by health ministry staff over the last two years, and salt iodine levels at the point of production have been routinely reported to be above $30 \mathrm{ppm}$ in at least $90 \%$ of the salt samples taken, a level that would provide sufficient amounts of iodine. This was judged by the review team to be a remarkable achievement considering the simple technology in use. However, owing to the wide 
variation in iodine content found in a small percentage of the samples, the team concluded that substantial changes in the procedures used to add iodine to salt were needed. Four different methods of salt iodization were observed by the team at six randomly selected processing plants; two of these methods were judged to be inherently unreliable and a third required a fine control mechanism that was not in place at the facilities visited.

The visits to the plants, which were carried out without advance notice, did confirm that all salt destined for human consumption was being iodized at the time of the review team's visit. Key workers at each of the sites visited were found to understand the need and importance of iodizing salt. The visits also provided the team with an opportunity to observe external quality control procedures by an inspector from the Program. The team was satisfied that salt sampling was done randomly and that processors understood the purpose and procedures of quality control, as well as the penalties associated with inadequate test results. However, results outside the required range of iodine content were not consistently followed up by appropriate enforcement action.

\section{CONCLUSIONS}

\section{Status of iodine deficiency in Bolivia}

On the basis of the available data on iodized salt production, iodized salt consumption, urinary iodine excretion, and international recommendations on criteria for elimination of IDD, the review team concluded that Bolivia has eliminated iodine deficiency disorders as a public health problem at the national level. The team inferred from this information that the consequences of iodine deficiency, such as new cases of endemic cretinism and mental retardation due to iodine deficiency in utero, are extremely rare or nonexistent.

The review team expressed concern, however, that analysis of disaggregated national data indicated that there may be pockets in some rural areas of Andean departments where iodized salt consumption and urinary iodine excretion are still relatively low. Therefore, the existence of isolated communities with inadequate iodine intake cannot be ruled out.

\section{Sustainability and improvement of the IDD control program}

Because the soil and water of Bolivia contain very little iodine, a reliable salt iodization program will need to continue for the foreseeable future. Although the review team asserted that Bolivia's achievements in controlling IDD were remarkable, it believed that there was absolutely no room for complacency, as there were several examples of other countries that had brought IDD under control only to have a resurgence of the disorders when governmental and popular support for the control program eroded. Even though the indicators of program impact in Bolivia were now above the internationally agreed minimum criteria, the team believed it was urgent and important to make a number of major improvements in the Program.

Based on the available information, the review team concluded that the prospects for sustainability of the Program were good, but that support to a number of critical areas would be essential to ensure sustainability.

\section{RECOMMENDATIONS}

The review team's report contains a series of detailed recommendations regarding surveillance of IDD and iodized salt use, standardization of laboratory methods, improvement of the production of iodized salt and salt quality control, and the structure and functions of the Program as a whole. The recommendations can be briefly summarized as follows:

- The Government should redouble its efforts to identify the small number of rural communities where low iodine intakes may still exist and ensure that iodized salt is consumed by all families in these communities.

- Government mechanisms to regularly assure salt quality at production and distribution points, and periodic surveys to monitor consumption of iodized salt and urinary iodine excretion, must be maintained and strengthened. The results of the monitoring systems must be brought to the attention of the highest levels of government as well as the general public and the salt industry in order to ensure the necessary action.

- Private-sector salt producers and packers should receive support and encouragement to improve their level of technology so as to reduce the batch-to-batch and day-to-day variability of the iodine content of salt and to implement a comprehensive quality assurance system.

- The concept that adequate iodine intake is the right of every Bolivian, in the context of Bolivia's implementation of the Convention on the Rights of the Child, should be further developed. One way of doing this is to ensure that knowledge of 
the history and causes of IDD in Bolivia and of the importance of consuming iodized salt is incorporated into all levels of the educational system, including training institutions for doctors and health workers.

\section{SINOPSIS}

\section{Eliminación casi total de los trastornos por deficiencia de yodo en Bolivia}

El Gobierno de Bolivia ha tenido desde 1983 un programa nacional para combatir los trastornos por deficiencia de yodo (TDY), que a principios de la década de 1980 afectaban a más de la mitad de la población del país. La principal estrategia empleada de forma sostenida en la lucha contra los TDY es la yodación de toda la sal destinada para consumo humano. En 1996, el Gobierno de Bolivia invitó a un grupo de expertos a revisar, en colaboración con los integrantes del programa dentro del país, cuánto se había avanzado hacia la eliminación de los TDY de todo el territorio nacional. El equipo revisor examinó los datos recolectados mediante las encuestas más recientes sobre la disponibilidad y el uso de la sal yodada y las concentraciones de yodo excretadas por la orina. Sobre la base de criterios internacionales establecidos para estos indicadores, el equipo llegó a la conclusión de que Bolivia habia eliminado los TDY como problema de salud pública de alcance nacional, pese a pruebas de que algunas comunidades aisladas de los Andes todavía carecían de una ingesta adecuada de yodo. El equipo hizo recomendaciones para mejorar el programa y garantizar su sostenibilidad. Asimismo, examinó los métodos de producción y el control de la calidad del proceso de yodación y recomendó medidas para reducir la variabilidad del contenido de yodo en la sal.

\section{REFERENCES}

1. World Health Organization. Indicators for assessing iodine deficiency disorders and their control through salt iodization. Geneva: WHO; 1994. (Document WHO/NUT/ 94.6)

2. IDD Newsletter $1995 ; 11$.

3. Instituto Nacional de Estadística and Macro International, Inc. Encuesta Na- cional de Demografía y Salud 1994Bolivia. Laz Paz, Bolivia, and Calverton, Maryland, USA: Instituto Nacional de Estadística and Macro International, Inc; October 1994.

4. Gutiérrez-S M. Encuesta Nacional de Múltiples Indicadores: Informe sobre consumo de yodo y contenido de yodo en orina [working document prepared for the International Committee to Evaluate the Impact of the IDD Elimination Program]. La Paz: Secretaría Nacional de Salud, Dirección Nacional de Epidemiología; 29 August 1996. (Final version). 